\section{VOLUNTEERS NEEDED TO PROMOTE CAREERS IN DENTISTRY}

Inspiring the future is a new, free volunteering service which helps people to volunteer in state schools and colleges to do short informal 'career insight' talks to help young people understand the world of work and about training routes, job and career options. The service has opened for registrations from employers and employees in all sectors and professions and hopes to receive registrations from members of the dental industry keen to promote dentistry to young people.

The service aims to help social mobility and get people from different backgrounds into the professions and says that it is a 'fantastic corporate social responsibility and self development opportunity'.

Employees (from CEOs to apprentices) visit a local school or college for half an hour simply to talk about the job they do and the route they took. No CRB check is needed as teachers will always be present. Individuals and organisations can register to take part for free via the Inspiring the future website: http://www.inspiringthefuture.org/

Inspiring the future is run by charity the Education and Employers Taskforce and the government, education and employer representative bodies such as the CBI, CIPD, FSB, IoD are supporting this initiative.

From 2012, Inspiring the future will also offer free volunteering opportunities from a wider menu of options such as mentoring and enterprise activity.

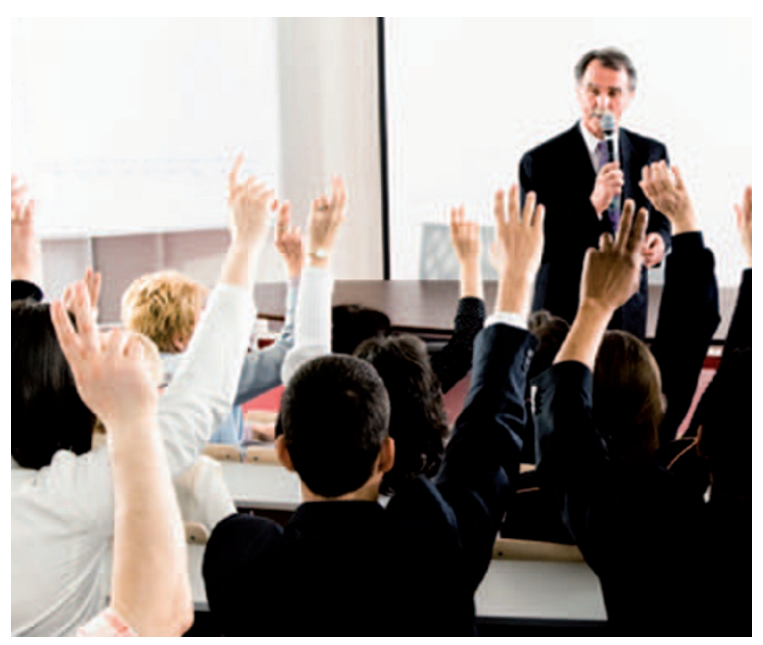

\title{
GLOBAL LEADERS UNITE IN FIGHT AGAINST CARIES
}

In Mexico City in September worldwide leaders in dentistry and public health gathered to kick off the Mexican chapter of the 'Alliance for a Cavity-Free Future', a global campaign to stop cavities.

The Alliance, which launched globally in September 2010, is a worldwide group of experts who have joined together to promote integrated clinical and public health action to stop caries initiation and progression. The group believes that global collaborative action is needed to challenge global leaders and other regional and local stakeholders to learn the importance of caries as a disease continuum where small initial caries lesions can be prevented and controlled before developing into gross cavities. The Alliance also works to drive and to participate in action toward the delivery of comprehensive caries prevention and management.

Led by Dr Heriberto Vera, former Chief Dental Officer for Mexico and the Chairman of the Mexican Alliance Chapter, key influencers in oral health and public health from Mexico showed their support for a new approach to caries and signed a declaration committing to the goals of the Alliance.

'At the global level, we continue to learn the importance of how cavities occur along a continuum and how important it is to detect and treat caries early in order to prevent the formation of cavities,' said Dr Nigel Pitts, Chairman of the global Alliance. 'We are excited to have the opportunity to work with Mexico and its dedicated dental and public health community to bring this new awareness about caries to the country and its people.'

In an effort to raise awareness about caries and how to prevent it, the Alliance unveiled a free, online consumer website that provides information about caries and resources to help prevent and manage early cavities. On the website, individuals and families who are committed to stopping early cavities can learn about caries and download a checklist to help assess their current oral health habits. After completing the items on the checklist, consumers receive a Certificate of Completion, demonstrating their commitment to oral health. To access the website visit www. AllianceForACavityFreeFuture.org

\section{DIARY}

S4S: Snoring - a role for the GDP

Date: 2 January 2012

Location: London

Telephone: 01142500176

www.s4sdental.com

ADI Masterclass: Maxillary Alveolar Ridge Regenerative Strategies

Date: 26 March 2012

Venue: Royal College of Surgeons

of England, London

Early-bird fee before 16 December 2011

Telephone: 02084875555

www.adi.org.uk/masterclass2012

Dental Protection

Dento-Legal Study Day

Date: 30 March 2012

Location: London

Telephone: 02073992914

http://www.dentalprotection.org/uk/

events/dlsd2012

13th Congress of the World

Federation of Laser Dentistry

Date: 26-28 April 2012

Location: Barcelona

Email:wfld2012@kenes.com

www.wfld-barcelona2012.com

British Dental Conference

and Exhibition 2012

Date: 26-28 April 2012

Venue: Manchester Central

Convention Complex

www.bda.org/conference

Excellence in Dentistry

2012 Conference

Date: 26-29 April 2012

Location: Istanbul

www.excellence-in-dentistry.org

The Clinical Innovations

Conference 2012

Date: 18-19 May 2012

Venue: Millennium Gloucester

Hotel \& Conference Centre,

London Kensington

www.clinicalinnovations.co.uk

Dental Sedation Teachers Group

Annual Symposium 2012

Date: 22 May 2012

Venue: St. Paul's Mecure Hotel, Sheffield

Email: sheelah.harrison@sheffield.ac.uk www.dstg.co.uk

11th Congress of the European Academy of Paediatric Dentistry A Crossroads of Knowledge, Innovation and Expertise

Date: 24-27 May 2012

Venue: Convention Centre,

Strasbourg, France

www.eapd2011.eu 